\title{
SUMMER OZONE CONCENTRATIONS IN ZAGREB AREA
}

\author{
Gordana PEHNEC, Vladimira VAĐIĆ, Ivan BEŠLIĆ, and Silva ŽUŽUL \\ Institute for Medical Research and Occupational Health, Zagreb, Croatia
}

Received in June 2008

Accepted in October 2008

\begin{abstract}
Ozone concentrations were measured at three sites in Zagreb (Croatia) in the summer of 2005. Two measuring sites were in urban areas, while the third site was in a rural area about $30 \mathrm{~km}$ to the south from the centre of Zagreb. Hourly ozone averages varied between $1 \mu \mathrm{g} \mathrm{m}^{-3}$ and $209 \mu \mathrm{g} \mathrm{m}{ }^{-3}$. Average concentrations were the lowest in the rural area, even though elevated concentrations were recorded occasionally. However, the weather conditions during measurements were untypical for that time of the year; over the summer of 2005 there were many rainy and cloudy days. Ozone concentrations at all three sites were the highest on Saturdays and Sundays, and the lowest on Thursdays. All the results were analysed with regard to the meteorological conditions (wind velocity and direction, temperature, relative humidity).
\end{abstract}

KEY WORDS: air, meteorological conditions, nitrogen dioxide, rural area, urban area

Zagreb is the capital of Croatia, situated in the northeastern part of the country, at the foot of Mt Medvednica (altitude $1035 \mathrm{~m}$ a.s.1.) to the north and by the River Sava to the south. The climate is continental. There are about 780,000 inhabitants living in the city and additional 310,000 living on the outskirts. Although the first measurements of ozone in Zagreb were carried out in the summer of 1975 $(1,2)$, they have become continuous since 1999 , and have been used to assess air quality. Today there are six stations that measure ozone concentrations in the city using automatic devices or manual methods. Our measurements have shown that ozone concentrations sometimes exceed the levels set by Croatian legislation $(3,4)$. Presently, ozone concentrations in Zagreb suburbia may be higher than in the city due to the transport of ozone precursors (5-7). In towns, where the traffic emission is high, ozone reacts with other species, especially with NO. At the same time, some ozone precursors are stable and may be transported by air masses to long distances. However, continuous measurements of ozone pollution have not been conducted in Zagreb suburbia. Measurements obtained by passive and active samplers in the summer of 2000 showed higher ozone concentrations in the suburbia than in the city. The highest values were obtained about $30 \mathrm{~km}$ to the south from the city centre during a heat wave in August 2000. From 13 to 28 August, daily averages exceeded $180 \mu \mathrm{g} \mathrm{m}^{-3}$ (3). For this reason we decided to repeat ozone measurements south of Zagreb using an automatic device, and to compare them with measurements in the city. To find the main causes of high ozone concentrations in the suburbia, we analysed all results taking into account meteorological conditions (wind velocity and direction, temperature, relative humidity). Data on nitrogen dioxide $\left(\mathrm{NO}_{2}\right)$ concentrations from two measuring sites in the city were analysed in order to establish ozone variations over the week.

\section{METHODS}

Ozone concentrations were measured at three sites in Zagreb and its suburbs from 1 July to 1 October 2005. The first site was in a residential, northern part, 
with low traffic density. The second site was in the city centre, with high traffic density. The third measuring site was in a sparsely populated rural area about $30 \mathrm{~km}$ to the south from the Zagreb centre, about $10 \mathrm{~km}$ to the south from the town of Velika Gorica, and at $100 \mathrm{~m}$ distance from a major road (Figure 1). All three sites were approximately at the same altitude: residential north at $161 \mathrm{~m}$ a.s.1., centre at $120 \mathrm{~m}$ a.s.l., and south suburbs at $160 \mathrm{~m}$ a.s.l. The last site is typical for that suburban area. Houses are typically located along roads, with fields behind the buildings. This is the same location where the highest ozone values were measured in the summer of 2000.

Ozone concentrations were measured using commercial automatic devices based on UV absorption at $254 \mathrm{~nm}$. For measurements in the residential north and in the centre, we used HORIBA APOA-360 ozone analysers, and for the south suburbia, the Environnement $41 \mathrm{M}$ ozone analyser. The limits of detection were $1 \mu \mathrm{g} \mathrm{m}^{-3}(0.5 \mathrm{ppb})$ and $2 \mu \mathrm{g} \mathrm{m}^{-3}$ (1 ppb), respectively. HORIBA APOA-360 ozone analysers were serviced and calibrated using four different set concentrations once a year. Daily quality assessment included zero- and span-checking (using one set concentration) using the HORIBA AFCU$360 \mathrm{RC}$ calibration system. The instrument used in the north was tested at the intercomparison workshop organised by the World Health Organization in Langen, Germany (May 2006). The instrument used in the rural area was also serviced and calibrated once a year, using zero- and span-checking of one set concentration for quality assessment. The accuracy of the Environnement $41 \mathrm{M}$ ozone analyser had been tested at earlier intercomparison workshops organised by the World Health Organization in Langen, Germany (in May 1999 and May 2002). There was also an intercomparison between the instruments used

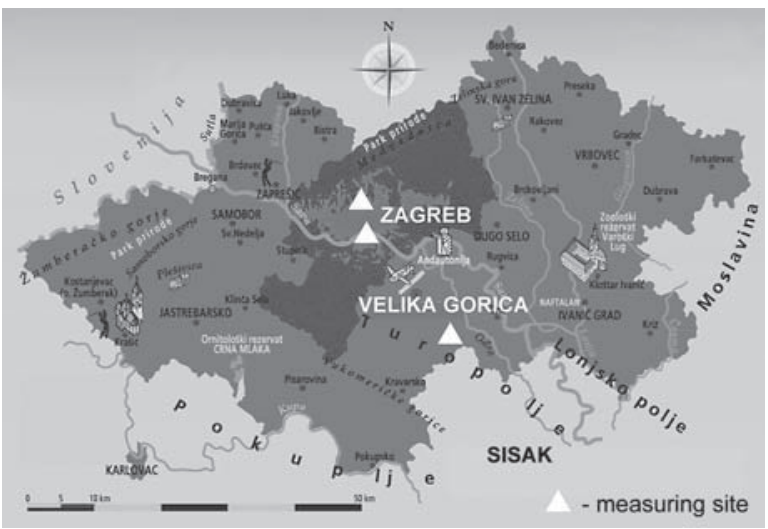

Figure 1 The location of the measuring sites in the north and in the south. The sites in the northern part and in the centre of Zagreb are part of the city and national network for air quality monitoring. In the north, ozone had been measured using an automatic device since 1996, and in the centre since 2004. The measuring site in the city centre is a part of the national network for continuous air quality monitoring organised by the Croatian Ministry of Environmental Protection, Physical Planning and Construction (8).

In the north, meteorological parameters (temperature, relative humidity, wind velocity and direction) were obtained using an automatic measuring station. Meteorological conditions for the suburban site and for the city centre were obtained from the nearest respective meteorological stations.

We measured $\mathrm{NO}_{2}$ concentrations in the northern part of Zagreb using an HORIBA APNA-360 $\mathrm{NO}_{\mathrm{x}}$ analyser with the detection limit of $1 \mu \mathrm{g} \mathrm{m}^{-3}(0.5$ $\mathrm{ppb}$ ). Data on $\mathrm{NO}_{2}$ concentrations in the centre were obtained from the Ministry of Environmental Protection, Physical Planning and Construction web site (8). For $\mathrm{NO}_{2}$ measurement, the Ministry used the same instrument with the same detection limit as we did. Both instruments were checked and serviced in the same way as ozone monitors. NO concentrations were not included in the study because the Croatian Air Protection Act does not stipulate a limit value for that pollutant.

\section{RESULTS AND DISCUSSION}

Based on the obtained data, we calculated daily, hourly, and eight-hourly ozone averages. Tables 1 and 2 show the results of ozone measurements at all three sites. Means, medians, standard deviations, and minimum and maximum values were calculated for hourly and daily averages. In the northern, residential part of the city, hourly averages ranged between $10 \mu \mathrm{g} \mathrm{m}^{-3}$ and $209 \mu \mathrm{g} \mathrm{m}^{-3}$. In the centre, hourly ozone concentrations ranged between $10 \mu \mathrm{g} \mathrm{m}^{-3}$ and $183 \mu \mathrm{g} \mathrm{m}^{-3}$. In the southern suburbs, hourly ozone concentrations were between $1 \mu \mathrm{g} \mathrm{m}^{-3}$ and $121 \mu \mathrm{g} \mathrm{m}^{-3}$.

Daily averages ranged between $11 \mu \mathrm{g} \mathrm{m}^{-3}$ and $137 \mu \mathrm{g} \mathrm{m}^{-3}$ in the north, between $13 \mu \mathrm{g} \mathrm{m}^{-3}$ and $98 \mu \mathrm{g} \mathrm{m}^{-3}$ in the centre, and between $3 \mu \mathrm{g} \mathrm{m}^{-3}$ and $60 \mu \mathrm{g} \mathrm{m}^{-3}$ in the southern suburbs.

The Croatian Air Protection Act (9), Regulation on Ozone in Ambient Air (10), and Regulation on Alert Thresholds of Pollutants in Ambient Air (11) define alert thresholds, tolerable and limit values 
for hourly, eight-hourly, and daily ozone averages. In accordance with the EU Directive 2002/3/EC (12), the alert threshold for the hourly average is $180 \mu \mathrm{g} \mathrm{m}^{-3}$ and the limit value for eight-hour running average is $120 \mathrm{\mu g} \mathrm{m}^{-3}$. There is also a limit value of $110 \mu \mathrm{g} \mathrm{m}^{-3}$ for 24-hour averages. The purpose of this study was not to categorise an area according to ozone pollution, because this requires at least a whole-year measurement. Our measurements were carried out only over the summer months. However, this is the most interesting part of the year because the highest values are usually recorded over the summer, when the sunlight is the most intense. In this study, hourly alert threshold of $180 \mu \mathrm{g} \mathrm{m}^{-3}$ was exceeded 12 times in the north and once in the city centre (Table 1). Eighthour averages did not exceed the $120 \mu \mathrm{g} \mathrm{m}^{-3}$ limit in the city centre and in the suburbia, but exceeded it in the north on four days. Daily averages exceeded the $110 \mu \mathrm{g} \mathrm{m}^{-3}$ limit only in the north (Table 2).

Figure 2 shows daily variations of ozone concentrations in the north, city centre and in the southern suburbia. Daily variations were similar in the north and the city centre. In the suburbia, ozone concentrations peaked between $12.00 \mathrm{~h}$ and $14.00 \mathrm{~h}$, while at other sites maximum values were recorded between $14.00 \mathrm{~h}$ and $17.00 \mathrm{~h}$.

Average ozone concentrations in the city (north and centre) were similar (see Tables 1 and 2). Medians were higher in the centre, but in the north they showed greater variability and twice as high standard deviation. The northern residential area also showed the highest hourly and daily values and it most often exceeded the limit values compared to other measuring sites. The centre and the north were both influenced by traffic pollution, but due to the lower traffic density in the north than in the centre, ozone was less consumed in the reaction with $\mathrm{NO}$, leaving thus room for occasional high $\mathrm{O}_{3}$ values. The same timing of daily ozone peaks (Figure 2) at both locations in the city is corresponded to the $\mathrm{NO}_{\mathrm{x}}$ peaks caused by increased traffic density in rush hours.

In our 2005 measurements, southern suburbia had the lowest ozone concentrations. This is quite unlike the 2000 summer measurements at the same site (3), and also unlike other European measurements in similar suburbs $(5,6)$.

Many authors $(13,14)$ analysed differences in ozone concentrations between weekend and weekdays. Ozone concentrations are closely related to the concentrations of its precursors, especially $\mathrm{NO}_{2}$. On weekends, traffic intensity is usually lower, and so

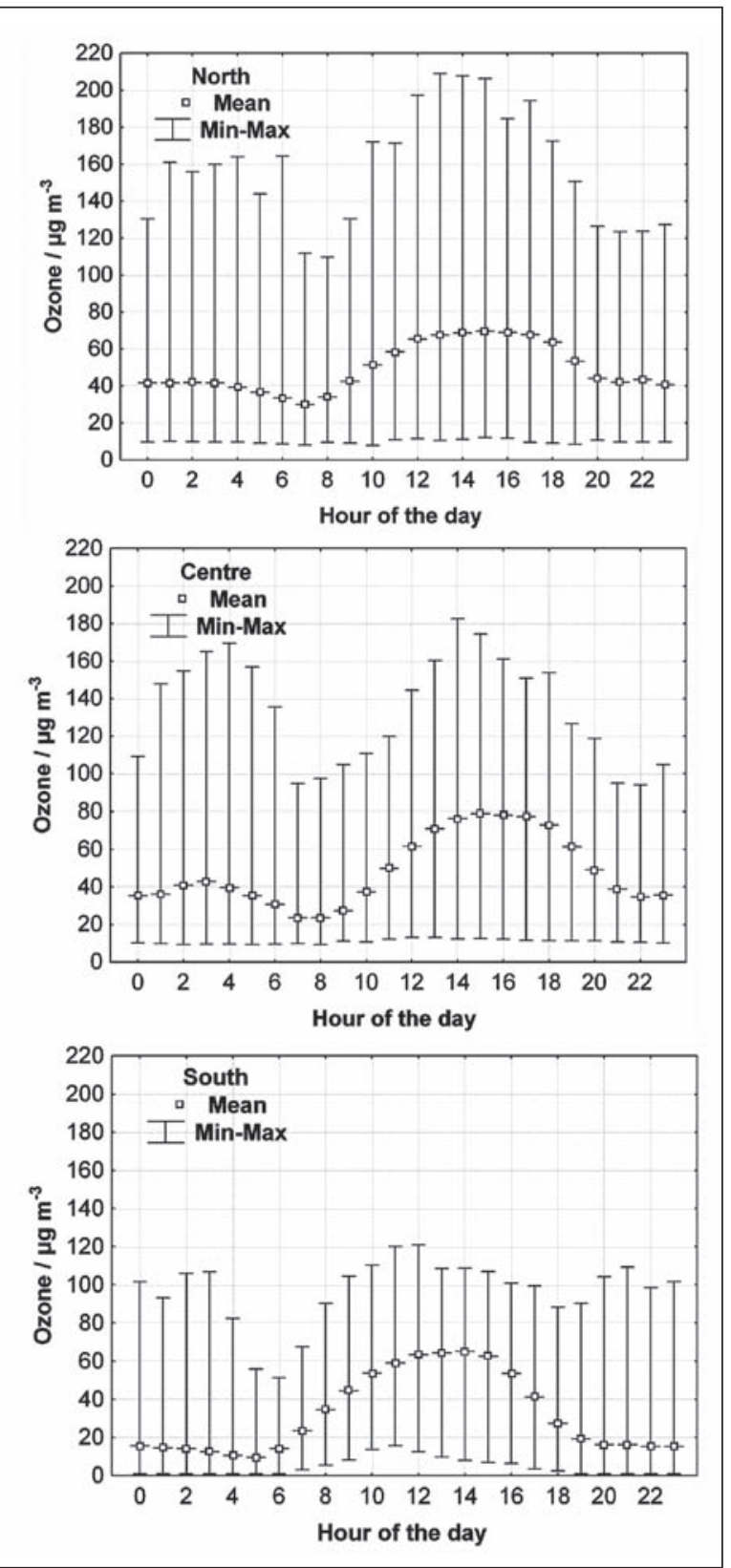

Figure 2 Daily ozone variations

is $\mathrm{NO}_{2}$ emission (and the emission of some organic compounds). Considering the mechanism of $\mathrm{NO}_{2}$ photolysis, it is expected that ozone concentration will decrease with decreasing $\mathrm{NO}_{2}$. However, measurements showed that ozone concentrations often increased on weekends $(13,14)$. There are several causes for such ozone behaviour, for example a reduction in $\mathrm{NO}_{\mathrm{x}}$ emissions on weekends that reduces the titration of ozone with $\mathrm{NO}$; a weekend change in the timing of $\mathrm{NO}_{x}$ peak that allows more efficient production of ozone; increased sunlight caused by a reduction in the amount of soot in the air; carryover of 
vehicle emissions near the ground and aloft; or increase in weekend emissions, particularly from off-road sources (domestic heating, lawnmowers etc.). In this paper, average ozone concentrations were calculated for every day of the week at all three sites. Figure 3 shows variations of average ozone concentrations over the week. At all three sites ozone concentrations were the lowest on Thursdays and the highest on Saturdays and Sundays. A statistical $t$-test was performed to test the differences in $\mathrm{O}_{3}$ concentrations between the days of the week. It showed no statistically significant difference between weekdays at either site. In the north and in the south, the difference in ozone levels between weekdays and weekends was also not significant $(t<0.992$ and $t<1.498$, respectively, $\mathrm{P}<0.05$ ). However, a statistically significant difference was found between Wednesdays and weekends in the city centre $(t$ between 2.542 and 3.095, $\mathrm{P}<0.05$ ) and Thursdays and weekends ( $t$ between 2.845 and $3.371, \mathrm{P}<0.05$ ). Ozone concentrations on Tuesdays and Fridays also significantly differed from Sundays $(t>2.599, \mathrm{P}<0.05)$.
$\mathrm{NO}_{2}$ concentrations were measured in the northern residential area and in the centre at the same time. Table 3 shows daily $\mathrm{NO}_{2}$ concentrations. Daily averages varied from $4.5 \mu \mathrm{g} \mathrm{m}^{-3}$ to $27.4 \mu \mathrm{g} \mathrm{m}^{-3}$ in the north (average $14.5 \mu \mathrm{g} \mathrm{m}^{-3}$ ) and from $10.3 \mu \mathrm{g} \mathrm{m}^{-}$ ${ }^{3}$ to $44.4 \mu \mathrm{g} \mathrm{m}^{-3}$ (average $29.4 \mu \mathrm{g} \mathrm{m}^{-3}$ ) in the city centre where they were the lowest on Fridays and Saturdays and the highest on Wednesdays. In the north, the lowest $\mathrm{NO}_{2}$ concentrations were observed on Saturdays and Sundays and the highest on Thursdays (Figure 4). Student $t$-test between average $\mathrm{NO}_{2}$ values showed that in the north $\mathrm{NO}_{2}$ concentrations did not significantly differ between weekdays. However, a statistically significant difference was found between any of the weekdays and weekends ( $t$ between 2.460 and 4.108, $\mathrm{P}<0.05$ ). Concentrations did not differ significantly between Saturdays and Sundays. Friday $\mathrm{NO}_{2}$ concentrations in the city centre were significantly lower than on other weekdays $(t$ between 2.781 and 4.256, $\mathrm{P}<0.05)$. Saturday $\mathrm{NO}_{2}$ levels were the lowest, and were significantly different from all other days in the week, including Sunday $(t$ between

Table 1 Descriptive statistics for hourly ozone mass concentrations $(\gamma)$ between 1 July and 1 October 2005

\begin{tabular}{lccccccc}
\hline $\begin{array}{lccccc}\text { Measuring } \\
\text { site }\end{array}$ & $\mathbf{N}$ & Minimum & Median & Mean & $\begin{array}{l}\text { Standard } \\
\text { deviation }\end{array}$ & Maximum & N>180 \\
\cline { 3 - 7 } & & 9.6 & 22.4 & 44.6 & 41.6 & 209.0 & 12 \\
North & 2205 & 10.1 & 39.5 & 46.7 & 24.0 & 182.5 & 1 \\
Centre & 2115 & 1.0 & 24.5 & 31.9 & 22.3 & 121.0 & - \\
South & 2189 & & & & &
\end{tabular}

$N$ - number of hourly averages

$N>180$ - number of hours with ozone concentrations higher than $180 \mu \mathrm{g} \mathrm{m}^{-3}$

Table 2 Descriptive statistics for daily ozone mass concentrations $(\gamma)$ between 1 July and 1 October 2005

\begin{tabular}{lccccccc}
\hline $\begin{array}{lcccccc}\text { Measuring } \\
\text { site }\end{array}$ & $\mathbf{N}$ & Minimum & Median & Mean & $\begin{array}{l}\text { Standard } \\
\text { deviation }\end{array}$ & Maximum & \multirow{2}{*}{$>\mathbf{1 1 0}$} \\
\cline { 3 - 7 } North & 92 & 11.4 & 21.4 & 44.7 & 34.4 & 137.2 & 4 \\
Centre & 92 & 13.3 & 43.2 & 46.7 & 17.0 & 98.2 & - \\
South & 92 & 3.3 & 32.1 & 31.9 & 11.4 & 60.0 & - \\
\hline
\end{tabular}

$N$ - number of daily averages

$N>110$ - number of days with ozone concentrations higher than $110 \mu \mathrm{g} \mathrm{m}^{-3}$

Table 3 Descriptive statistics for daily nitrogen dioxide mass concentrations ( $\gamma$ ) between 1 July and 1 October 2005

\begin{tabular}{lcccccc}
\hline $\begin{array}{l}\text { Measuring } \\
\text { site }\end{array}$ & $\mathbf{N}$ & Minimum & Median & Mean & $\begin{array}{c}\text { Standard } \\
\text { deviation }\end{array}$ & Maximum \\
\cline { 3 - 6 } & 92 & 4.5 & 14.6 & 14.5 & 4.74 & 27.4 \\
North & 85 & 10.3 & 29.4 & 29.4 & 8.27 & 44.4 \\
\hline
\end{tabular}

$N$-number of daily averages 
2.781 and 6.279, $\mathrm{P}<0.05)$. The highest difference between weekday and weekend ozone concentrations was recorded in the city centre with higher average $\mathrm{NO}_{2}$ levels and higher $\mathrm{NO}_{2}$ variations.

Over the measuring period, hourly temperature averages ranged between $3.9{ }^{\circ} \mathrm{C}$ and $42.3{ }^{\circ} \mathrm{C}$ while relative humidity ranged between $19 \%$ and $98 \%$. However, the whole summer of 2005 was atypical, colder than usual, and with as many as 33 rainy days. In contrast, the summer of 2000 , when preliminary ozone measurements were made, was very hot, with many sunny days. This is probably the main reason for the lower ozone concentrations at the suburban location in the summer of 2005 than of 2000 . At the same time, ozone levels in the city were the same or even higher over the summer of 2005 than the summer of 2000 (3). These findings can not only be explained by more or less sun radiation (in which case 2005 ozone levels should be low at all three locations).

Linear correlation coefficients were calculated between hourly ozone concentrations and temperature and relative humidity. As expected, a statistically significant positive correlation was found between ozone concentrations and temperature ( $\mathrm{r}$ between 0.57 and $0.61 ; \mathrm{P}<0.001$ ) and negative correlation between ozone and relative humidity ( $\mathrm{r}$ between -0.39 and $-0.79 ; \mathrm{P}<0.001)$ at all three sites. An increase in temperature and lower humidity are the result of higher solar radiation. At the same time, solar radiation has a key role in ozone formation (ozone is formed through photochemical reactions of nitrogen oxides and volatile organic compounds). Although there is no causal relationship between ozone, temperature, and relative humidity, high temperature and low relative humidity are connected with higher sun radiation and sometimes may be the indicators of high ozone values.

Data on wind direction and wind velocity were analysed as well. Unfortunately, we did not have hourly data on wind direction at these three locations for the summer of 2000, but only for the summer of 2005. Although the most dominant winds in Zagreb area are north and northeast winds (2), the wind roses at measuring sites did not show the same pattern because they were influenced by the local setup (buildings, trees, shelters). Figure 5 shows the wind roses for all three sites for the period 1 July - 1 October 2005. The most frequent wind in the northern part of Zagreb was SSE. Average wind velocity was less than $0.52 \mathrm{~m} \mathrm{~s}^{-1}$ from all directions. The wind with the highest average velocity was SEE and with the lowest NNE (Figure 5a). The highest average ozone concentrations (more than $80 \mu \mathrm{g} \mathrm{m}^{-3}$ ) were associated with winds from directions SE, SSE, and WNW. The lowest concentrations were connected with winds from the NNE direction. SE and SSE winds bring pollutants from the city centre to the north (Figure 1) while the nearest road is in the WNW direction.

In the city centre, the predominant winds were ENE, E, and ESE. Winds blowing from N and NW were less frequent. Average wind velocity was the highest from directions NE, ENE, and E (Figure 5b). However, the wind rose in Figure $5 \mathrm{~b}$ (3) shows that the average ozone concentrations did not significantly depend on wind direction, although the highest average ozone concentrations were associated with both $\mathrm{E}$ and $\mathrm{W}$ winds. The lowest concentrations were associated with winds from $\mathrm{N}$ and NW directions. This suggest that ozone levels in the city centre were not influenced by the transport of pollutants from other sectors.

In the southern suburbia, the most frequent winds were NNE, W, and ESE. The highest average wind velocity was that of NNE (Figure $5 \mathrm{c}$ ). The highest average ozone concentrations (more than $40 \mu \mathrm{g}$ $\mathrm{m}^{-3}$ ) were associated with NNE and NE winds and with SW and SWS winds (Figure 5c). The lowest concentrations were associated with $\mathrm{W}$ and SSE winds. These findings suggest that ozone levels at this site depend on $\mathrm{N}$ and $\mathrm{NE}$ winds (coming from the

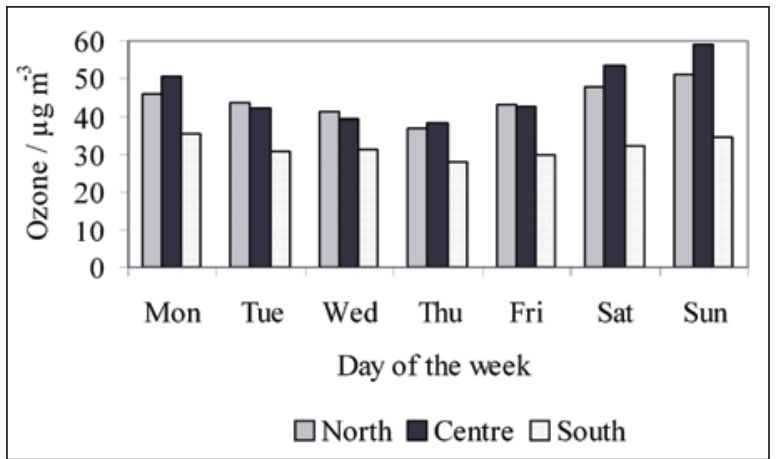

Figure 3 Weekly average ozone variations

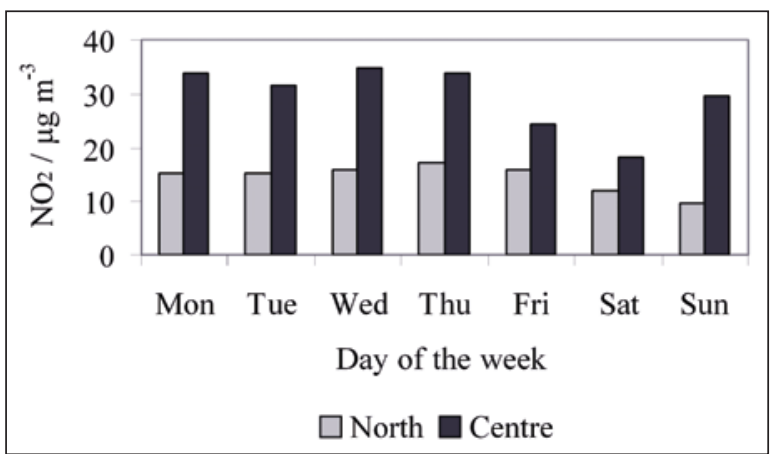

Figure 4 Weekly average nitrogen dioxide variations 


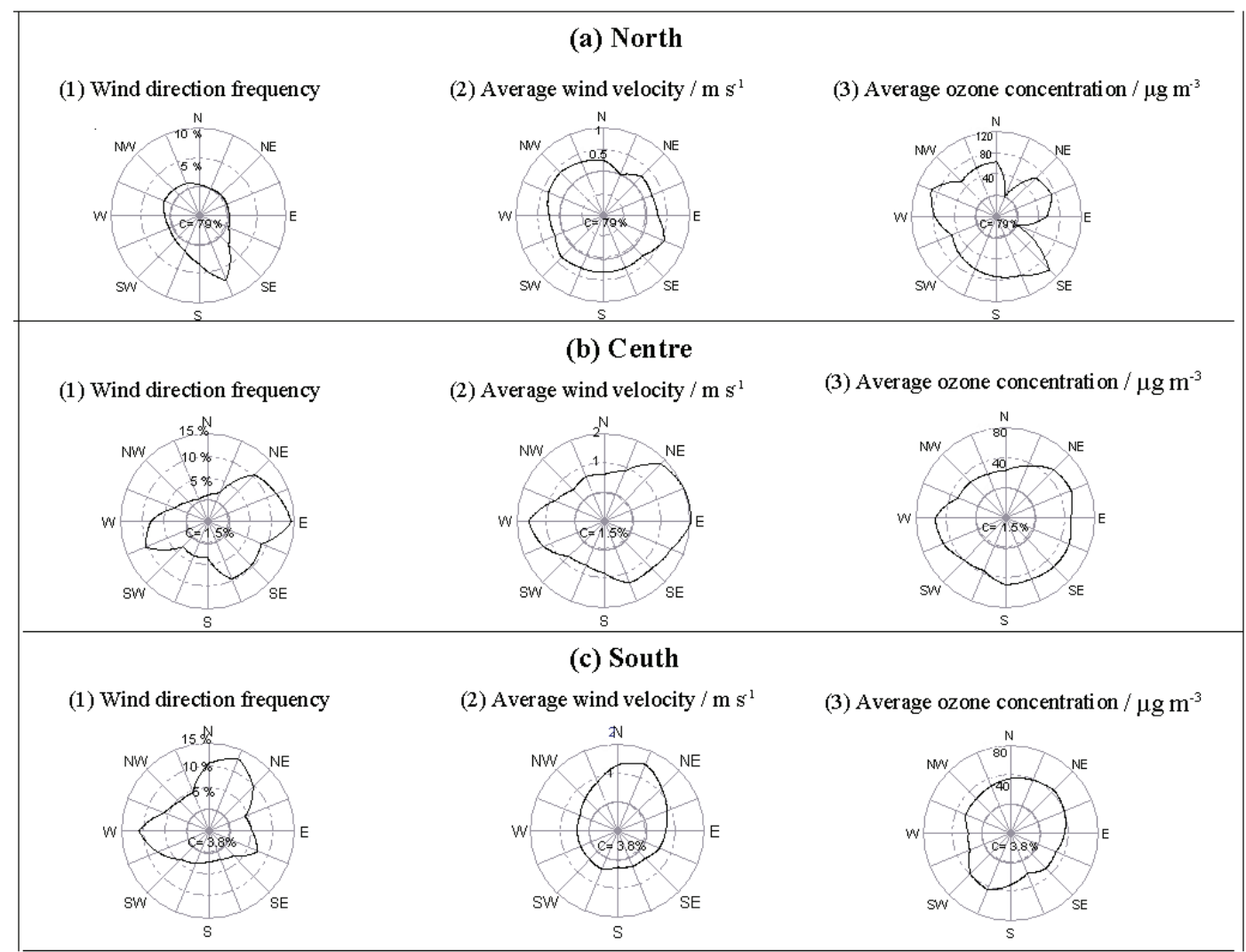

Figure 5 Wind roses at the three measuring sites in Zagreb and its surroundings between 1 July and 1 October 2005

centre of Zagreb) and on SW winds (coming from the Zagreb-Sisak highway, and from the town of Sisak, see Figure 1). The westerlies, although frequent, did not elevate ozone concentrations (the area to the west from the suburbia measuring site is sparsely populated with low traffic and no other pollution sources).

\section{CONCLUSION}

Ozone concentrations at the measuring sites located in the city (north and centre) showed a similar variation over the day and over the week. Although similar average ozone values were obtained, they varied more in the north, and were occasionally extremely high. Winds from the south (Zagreb centre) bring ozone precursors to the north. Ozone formed at that location, due to the lower traffic density than in the centre, is less consumed in the reaction with NO.

Ozone in the city centre was not influenced by the transport of pollutants from other sectors, but from local pollution sources (road traffic).
In the southern, suburban area, ozone pollution was associated with the northerlies from Zagreb and with the southerlies from Sisak. This southern area, however, showed the lowest ozone concentrations in the summer of 2005. They never exceeded the limits set by Croatian legislation. This may be explained by meteorological conditions. The whole summer of 2005 was rainy and air pollutants were removed from the atmosphere by wet deposition. Since the transport of ozone and its precursors became difficult due to frequent rainfalls, a ratio between $\mathrm{NO}_{\mathrm{x}}$ and volatile organic compounds required for the $\mathrm{O}_{3}$ formation was not established at the suburban location. In contrast, high ozone concentrations measured in the summer of 2000 suggest that elevated ozone values may be expected in that area in dry and hot weather. Our results show that ozone levels may differ significantly from year to year due to meteorological conditions. Thermal regime and wind direction influence on the differences between ozone levels at different measuring sites. This is why continuous ozone measurements are necessary in Zagreb suburbia, populated by nearly 300,000 people. 


\section{Acknowledgments}

We are grateful to the Ministry of Environmental Protection, Physical Planning and Construction for the data on ozone and nitrogen dioxide concentrations measured in the city centre. This work was supported by the Ministry of Science, Education and Sports, Republic of Croatia (grant no. 022-0222882-2338).

\section{REFERENCES}

1. Božičević Z, Klasinc L, Cvitaš T, Güsten H. Photochemical ozone formation in the lower atmosphere above Zagreb [Photochemische Ozonbildung in der unteren Atmosphäre über der Stadt Zagreb, in Deutsch]. Staub 1976;36:363-6.

2. Cvitaš T, Güsten H, Klasinc L. Statistical association of the photochemical ozone concentration in the lower atmosphere of Zagreb with meteorological variables. Staub 1979;3:925.

3. Pehnec G, Vadjić V, Hršak J. Measurements of ozone concentrations in Zagreb. Environ Monit Assess 2005; 105:165-74.

4. Alebić-Juretić A, Cvitaš T, Kezele N, Klasinc L, Pehnec G, Šorgo G. Atmospheric particulate matter and ozone under heat-wave conditions: do they cause an increase of mortality in Croatia? Bull Environ Contam Toxicol 2007;79:468-71.
5. European Environment Agency (EEA). Air pollution by ozone in Europe in 1998 and summer 1999. Copenhagen: EEA; 2000.

6. World Health Organization (WHO). Air Quality Guidelines for Europe. Regional Publications, European Series No. 23. Copenhagen: WHO; 1987.

7. World Health Organization (WHO). Air Quality Guidelines, Global Update 2005. Copenhagen: WHO; 2006.

8. Ministry of Environmental Protection, Physical Planning and Construction, MZOPUG [displayed 16 June 2008]. Available at http://www.zrak.mzopu.hr.

9. Zakon o zaštiti zraka [Air Protection Act, in Croatian]. Narodne novine 2004/178. p. 3082.

10. Uredba o ozonu u zraku [Regulation on Ozone in Ambient Air, in Croatian]. Narodne novine 2005/133. p. 2466.

11. Uredba o kritičnim razinama onečišćujućih tvari u zraku [Regulation on Alert Thresholds of Pollutants in Ambient Air, in Croatian]. Narodne Novine 2005/133. p. 2468.

12. EU Directive 2002/3/EC [displayed 16 June 2008]. Available at http://www.hart-isee.com/index.php?page=eu-policies.

13. Viras LG. Comparison of ozone levels between working days and weekends in Athens, Greece. Environ Monit Assess 2002;80:301-14.

14. Atkinson-Palombo CM, Miller JA, Balling RC Jr. Quantifying the ozone "weekend effect" at various locations in Phoenix, Arizona. Atmos Environ 2006;40:7644-58. 
Sažetak

\section{LJETNE KONCENTRACIJE OZONA NA PODRUČJU ZAGREBA}

Koncentracije ozona mjerene su na tri mjesta u Zagrebu tijekom ljeta 2005. godine. Dva mjerna mjesta bila su smještena u urbanom području dok se treće mjerno mjesto nalazilo u ruralnom području udaljenom oko $30 \mathrm{~km}$ prema jugu od centra Zagreba. Satni prosjeci masenih koncentracija ozona kretali su se između $1 \mu \mathrm{g} \mathrm{m}^{-3}$ i $209 \mu \mathrm{g} \mathrm{m}^{-3}$. Prosječne koncentracije bile su najniže u ruralnom području, premda su povremeno zabilježene i povišene vrijednosti. Međutim, vremenski uvjeti tijekom mjerenja bili su netipični za to doba godine - tijekom ljeta 2005. bilo je mnogo kišnih i oblačnih dana. Na sva tri mjerna mjesta koncentracije ozona bile su najviše subotom i nedjeljom, a najniže četvrtkom. Svi rezultati analizirani su s obzirom na meteorološke uvjete.

KLJUČNE RIJEČI: dušikov dioksid, meteorološki uvjeti, ruralno područje, urbano područje, zrak

\section{CORRESPONDING AUTHOR:}

\section{Gordana Pehnec}

Institute for Medical Research and Occupational Health Ksaverska cesta 2, 10000 Zagreb, Croatia

E-mail: gpehnec@imi.hr 